\title{
Metaphors in Contemporary Art
}

\section{Metafora Dalam Seni Kontemporari}

\author{
Wan Nurhasyimah W. Mohd Apandi ${ }^{1}$, Ahmad Rashdi Yan Ibrahim ${ }^{2}$ \\ Jabatan Seni Halus, Faculty of Art and Design, Universiti Teknologi MARA, Perak Branch, \\ Seri Iskandar Campus, 32610 Seri Iskandar, Perak, MALAYSIA \\ Authors' email: wannu829@uitm.edu.my², ahmadrashdi@gmail.com²
}

Published: 7 September 2018

\begin{abstract}
The use of metaphors in producing contemporary works of art is often used by artists to convey current ideas and issues in the era of contemporary visual art. The metaphor used is as a symbol for the meaning of a work in conveying the ideas and narrative of the story more creatively. In addition, the use of metaphors should be in line with the selection of subjects and meanings to be used and conveyed more accurately and effectively in the production of works to be seen and studied by art critics.
\end{abstract}

Keywords: Photography, artistic elements, art work, consciousness.

\begin{abstract}
ABSTRAK
Penggunaan metafora dalam menghasilkan karya seni kontemporari sering digunakan oleh artis seni bagi menyampaikan idea dan isu semasa dalam era seni visual kontemporari. Metafora yang digunakan ini adalah sebagai perlambangan bagi maksud sebuah karya dalam menyampaikan idea dan naratif penceritaan dengan lebih kreatif. Disamping itu juga, penggunaan metafora perlu selari dengan pemilihan subjek dan maksud yang ingin digunakan dan disampaikan dengan lebih tepat serta berkesan dalam penghasilan karya untuk dilihat dan dikaji oleh pengkritik seni.
\end{abstract}

eISSN: 2550-214X (C) 2018. The Authors. Published for Idealogy Journal of Arts and Social Science by UiTM Press. This is an Open Access article distributed under the terms of the Creative Commons Attribution-NonCommercial-NoDerivatives License (http://creativecommons.org/licenses/by-nc-nd/4.0/), which permits non-commercial re-use, distribution, and reproduction in any medium, provided the original work is properly cited, and is not altered, transformed, or built upon in any way.

\section{METAFORA}

Metafora adalah berasal dari perkataan Yunani yang bererti memindahkan. Dengan itu, metafora bermaksud sesuatu perkara, objek atau benda dijadikan sebagai perlambangan kepada sesuatu penceritaan atau tema yang ingin disampaikan dalam sebuah karya seni. Penggunaan metafora yang dipilih itu mestilah mempunyai keserasiaan bagi suatu penceritaan yang hendak disampaikan sebagai satu simbol perlambangan disebalik penceritaan atau makna yang ingin disampaikan oleh artis (Donald Davidson, 1978).

Disamping itu, menurut Kamus Dewan edisi ketiga (2000) terbitan Dewan Bahasa dan Pustaka, metafora bermaksud pemakaian kata - kata yang menyatakan sesuatu makna atau maksud yang lain daripada makna biasa ataupun makna sebenar sebagai perbandingan, kiasan atau perlambangan.

Merujuk William Shakespeare (2000) metafora merupakan sesuatu cara menerangkan dan mengambarkan sesuatu maksud bagi sebuah karya secara ringkas dan mudah dilihat atau ditafsir bagi mengambarkan sesuatu subjek atau objek yang bersesuaian dengan membuat andaian menggunakan objek ini sebagai makna perlambangan sebuah karya.

Menurut I.A Richards (1936) metafora mengandungi dua bahagian iaitu "Tenor" dan "Vehicle". Tenor merupakan subjek utama yang mempunyai sifat dan penceritaan sesuatu yang ingin disampaikan manakala Vehicle pula merupakan satu objek yang dipilih untuk dipinjamkan kepada subjek utama kerana Vehicle ini mempunyai sifat- sifat atau persamaan dengan cerita subjek utama. Oleh itu, jika 
sesorang artis itu memilih subjek sebagai metafora didalam karya seni kontemporari, metafora boleh berlaku kerana seni visual ini sendiri adalah vehicle yang diilhamkan oleh artis untuk menerangkan sesuatu penceritaan sebagai perlambangan ataupun perumpamaan.

\section{KEPENTINGAN METAFORA}

Menurut Donald Davidson (1978) metafora sebenarnya tidak bertapak diatas makna semata - mata tetapi tertumpu kepada penggunaan metafora tersebut . Fungsi metafora dalam seni catan ini adalah untuk memberikan satu ilustrasi sesuatu topik yang hendak disampaikan dan penggunaan metafora ini dapat membuat pengkritik seni dapat mentafsir dan menilai sesuatu karya dengan merangsang minda terhadap visual karya daripada artis.

Selain itu juga, metafora merupakan satu bahasa kiasan yang paling kerap menjadi alat sebagai perlambangan bagi sesuatu maksud dalam menghasilkan sesuatu karya seni. Dengan itu, metafora sebagai bahasa komunikasi yang dijelaskan dengan cara bahasa kiasan atau bahasa yang lebih halus untuk disampaikan kepada orang ramai sekiranya ingin menerapkan unsur nasihat, sindiran dan teguran dalam pemilihan subjek metafora dalam karya (Hamidah Abdul Hamid, 1995).

Dengan itu, penggunaan subjek sebagai metafora dalam karya seni kontemporari oleh artis itu perlu peka dari segi sensitiviti maksud bagi pemilihan subjek metafora dan perlambangan yang ingin disampaikan mengikut kesesuaian bagi sebuah penceritaan dalam karya. Pemilihan subjek yang tepat sebagai metafora dalam karya dapat memberi impak yang tinggi kepada pengkritik seni untuk dibahaskan dan dibincang dengan lebih mendalam tentang maksud yang ingin disampaikan oleh artis tersebut.

\section{PENGGUNAAN METAFORA DALAM SENI KONTEMPORARI}

Antara artis yang menggunakan metafora sebagai subjek didalam karya mereka ialah Prof. Jalaini Abu Hassan. Beliau banyak menggunakan subjek objek sebagai metafora didalam karya catan dalam menyampaikan naratif penceritaan dalam karya. Antara subjek yang digunakan dalam karya catan dan lukisan beliau adalah penggunaan buah tempatan, sayuran, barangan perkakas tradisional melayu, bunga kantan, cengkerang, daun paku - pakis, kukur kelapa, ayam jantan, pokok kelapa, pokok getah, rumah kayu dan lain - lain lagi (Azman Ibrahim, 1999). Disamping itu juga, artis sering menggunakan kata - kata peribahasa melayu sebagai metafora bagi menyampaikan maksud dam maklumat sebagai perlambangan dalam karya catan dan lukisan. Pengunaan subjek metafora didalam karya beliau jelas menunjukkan artis itu peka terhadap isu semasa, politik, ekonomi dan isu sosial yang berlaku disamping menerapkan dan merakam pengalaman peribadi terhadap kesan dan pengaruh tradisi budaya dalam menghasilkan karya. Dalam pembikinan karya dengan menggunakan subjek metafora, artis ini bijak menyusun imej bagi mencerminkan idea yang ingin disampaikan terhadap pemerhatian isu semasa yang berlaku ketika itu sebagai dokumentasi dalam penghasilan karya.

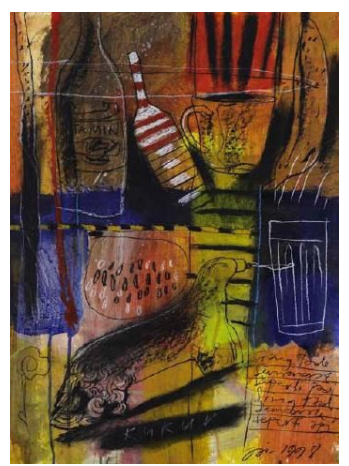

Rajah 1: Jalaini Abu Hassan, Kukur, 30" x 22 ", 1998, Media Campuran (Sumber Imej: Jai Drawing with The Mind's Eye)

Selain itu, terdapat artis arca seramik iaitu Umibaizurah Mahir yang telah menghasilkan arca 
seramik dan karya instalasi dengan menggunakan subjek metafora didalam karya arca. Antara subjek yang telah digunakan sebagai metafora adalah haiwan seperti zirafah, gajah, arnab, burung, anjing, ikan, sayur petola, kasut, bunga, anak patung, pistol dan lain - lain lagi. Menurut Noor Mahnun Mohamed (2018) pemilihan subjek seperti anjing didalam karya seramik oleh artis itu memberi perlambangan kepada persahabatan dan kesetiaan manakala penggunan subjek gajah dalam karyanya memberi pandangan kemegahan. Segala pemilihan subjek metafora ini digunakan dan dibuat menjadi karya arca dan instalasi mewakili perlambangan kepada pemerhatian artis ini terhadap kemanusiaan dan menyentuh isu - isu seperti cinta, kejujuran dan kesetiaan dalam konteks prinsip manusia dalam politik dan ekonomi. Penggunaan subjek ini jelas dapat dilihat dalam karya bentuk tiga dimensi walaupun subjek ini telah berlaku proses perkembangan idea dari segi rupa bentuk asal berubah kepada bentuk yang lebih dramatik kelihatan seperti anak patung dan permainan. Merujuk Ho Kay Tat (2016) penggunaan metafora bagi karya instalasi dalam pameran solo yang bertajuk "Fragile" artis ada menggunakan subjek zirafah dan sayuran sebagai metafora yang mewakili individu atau keluarga yang menghadapi masalah kewangan dan keluarga tersebut sanggup menjual barang berharga yang mereka miliki untuk bertahan meneruskan hidup mengikut kemahuan diri dan keluarga.

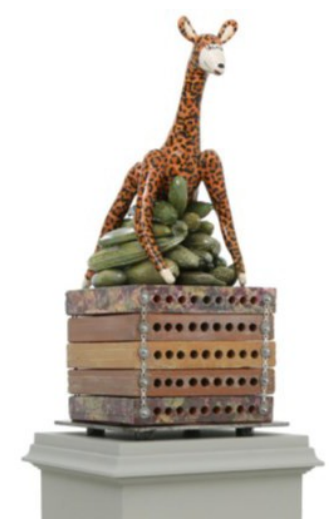

Rajah 2: Umibaizurah Mahir, The Orchard, 2015 - 2016, 77cm x 36cm x 36cm, Seramik dan Media Campuran (Sumber imej: Fragile by Umibaizurah Recent Works 2015 - 2016, 2016)

Artis lain yang menggunakan subjek metafora dalam karya seni kontemporari adalah Ahmad Zakii Anwar. Artis ini banyak menggunakan subjek di dalam karya catan sebagai metafora mewakili maklumat yang ingin disampaikan dalam pemerhatian artis ini terhadap isu sensitif seperti isu semasa, politik, kemanusiaan dan kehidupan. Ahmad Zaki gemar menggunakan subjek manusia, buah - buahan dan haiwan sebagai metafora dalam penghasilan karya catan dan lukisan. Menurut Anurendra Jegadeva (2008) antara subjek yang digunakan artis adalah objek yang bersifat nostalgia seperti pasu tembikar dan cerek yang menceritakan tentang setiap objek mempunyai nilai sensitiviti seperti kasih sayang dan ketekunan yang serupa disamping pemilihan subjek metafora ini dijadikan pengertian hidup yang penuh misteri. Pemilihan objek ini bersifat lebih emosi dan artis telah memberi ekspresi seni dalam karya, hal ini kerana segala karya Ahmad Zakii Anwar adalah mengenai pemikiran, jiwa dan pandangan diri sendiri tentang sesuatu perkara yang bermain diminda. Disamping itu, penggunaan buah - buahan sebagai metafora dalam karya adalah untuk memperkembangkan niat artis bagi perlambangan kesuburan, kelengkapan dan kesempurnaan. Artis ini bersifat lebih autobiografi dalam pemilihan subjek metafora untuk menghasilkan karya. Subjek metafora itu hanya sebagai alat untuk meluahkan apa yang artis fikirkan tentang isu sensitif yang berlaku di dalam persekitaran hidup artis dengan cara intelektual (Eddin Khoo, 2008). 


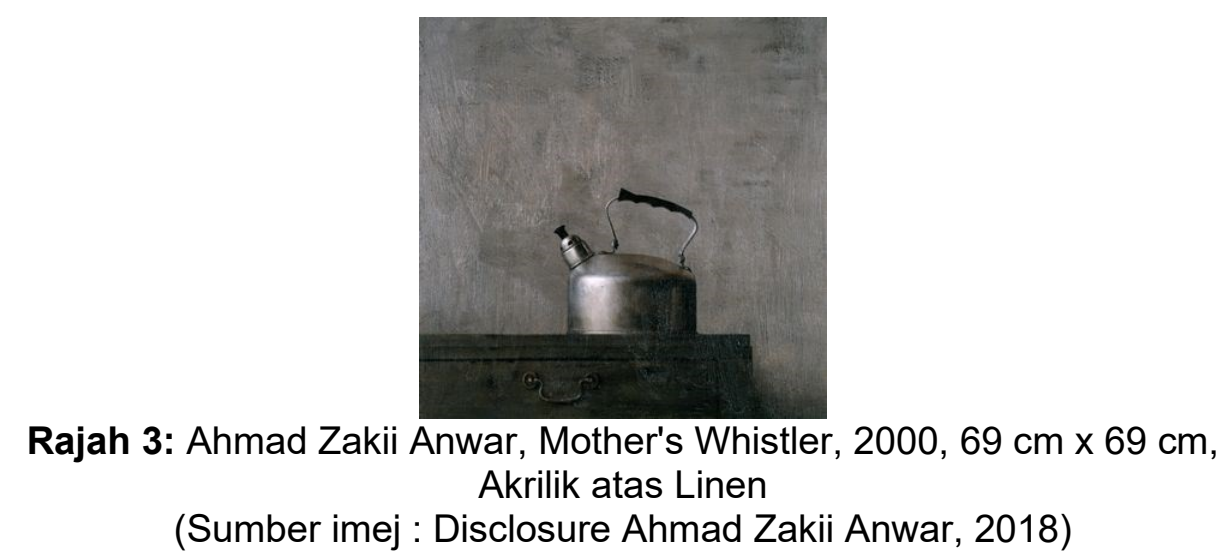

Selain itu, berbeza pula artis dari Bangkok, Thailand iaitu Natee Utarit yang menggunakan beberapa susunan objek dalam satu komposisi sebagai pemilihan subjek metafora dalam penghasilan karya seni catan. Antara subjek yang dipilih menjadi metafora dalam karya adalah, burung, arnab, itik, anjing, ular, kambing dan lain - lain lagi. Walau bagaimanapun, subjek metafora ini disusun dengan baik dengan beberapa objek komponen yang lain bagi menghasilkan satu pandangan dengan lebih efektif dan dramatik sewaktu pembikinan karya dalam menyampaikan mesej yang ingin diketengahkan oleh artis sebagai satu simbolik penceritaan. Menurut Nattee Utarit (2018) haiwan dijadikan subjek utama dalam catan sebagai metafora mewakili fenomena sosial dan politik dalam pandangan konteks sosial di dalam karya. Sebenarnya penggunaan haiwan sebagai metafora adalah penglihatan biasa digunakan oleh artis asia dan barat. Bagi artis subjek haiwan yang digunakan dalam karya ini juga mencerminkan sifat - sifat dan watak keperibadian manusia dan penggunaan subjek haiwan sebagai metafora ini mewakili makna dan merakam peristiwa tertentu secara umum seperti simbol perlambangan bagi suatu keagamaan (Natee Utarit, 2018).

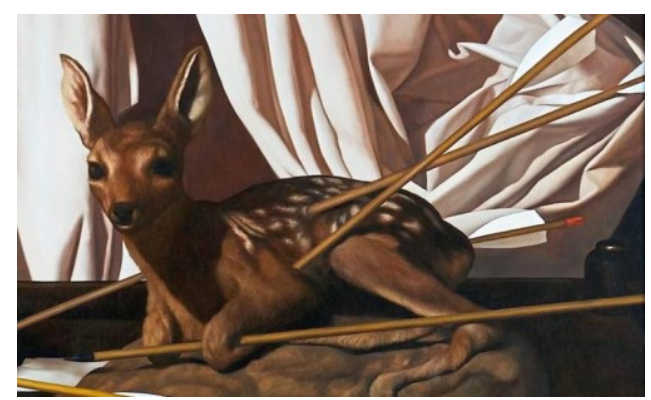

Rajah 4: Natee Utarit, Faith and Doubt, 2013, $160 \mathrm{~cm}$ x $140 \mathrm{~cm}$, Cat Minyak atas Linen

(Sumber imej: Natee Utarit : Optimism is Ridiculous)

\section{KESIMPULAN}

Secara kesimpulannya, penglibatan para artis dalam seni kontemporari dapat dilihat dengan jelas apabila mereka beraksi dengan bijak dalam pemilihan subjek sebagai metafora di dalam karya. Walaubagaimanapun, pemilihan subjek sebagai metafora ini memberi kesan positif dari segi pemahaman maksud perlambangan yang dipilih itu selaras dengan mesej yang ingin disampaikan. Secara tidak langsung penggunaan metafora ini dapat membuka minda pengkaji seni dalam memberi interpretasi makna dalam karya apabila visual imej bagi subjek metafora itu diterapkan didalam karya seni. 
Metaphors in Contemporary Art Metafora Dalam Seni Kontemporari

\section{RUJUKAN}

Anurendra Jegadeva, Rahel Joseph, A. Latif Mad Nor, K. Jesmail, 2008, Disclosure Ahmad Zakii Anwar, Kuala Lumpur, Galeri Petronas.

Azman Ibrahim, 1999, Jai Drawing with The Mind's Eye, Kuala Lumpur.

Donald Davidson, 1978, What Metaphors Mean. Oxford: Oxford University Press.

Hamidah Abdul Hamid, 1995, Pengantar Estetik, Kuala Lumpur: Dewan Bahasa dan pustaka.

Ho Kay Tat, Tony Godfrey, 2016, Fragile by Umibaizurah Recent Works 2015-2016, Kuala Lumpur, The Edge Gallerie.

I.A. Richard, 1936, The philosophy of Rhetoric, Oxford: Oxford University Press.

Kamus Dewan Bahasa Edisi Ketiga, 2000, Kuala Lumpur: Dewan Bahasa dan Pustaka. Natee Utarit, 2018, Optimism is Ridiculous, Kuala Lumpur, Richard Koh Fine Art Sdn. Bhd.

Noor Mahnun Mohamed, 2012, TAG Exhibition Umubaizurah Mahir@Ismail, Kuala Lumpur,WeiLing Gallery

William Shakespeare, 2000, As you like it, New York: Penguin Books 
Idealogy Journal of Arts and Social Science

Vol. 3 No. 2, 2018 